\title{
Role of Insulin: Perspectives
}

\author{
Gudisa Bereda \\ Department of Pharmacy, Negelle Health Science College, Guji, Ethiopia.
}

Corresponding Author: Gudisa Bereda, Department of Pharmacy, Negelle Health Science College, Guji, Ethiopia.

Received Date: 03 December 2021 | Accepted Date: 31 December 2021 | Published Date: 10 January 2022

Citation: Gudisa Bereda, (2022). Role of Insulin: Perspectives. J. Diabetes and Islet Biology, 5(1); DOI:10.31579/2641-8975/030

Copyright: (C) 2022 Gudisa Bereda, This is an open access article distributed under the Creative Commons Attribution License, which permits unrestricted use, distribution, and reproduction in any medium, provided the original work is properly cited.

\begin{abstract}
The pancreas in a non-diabetic patient invariably produces a lesser quantum of insulin (basal production). Insulin furnishes glucose homeostasis by keeping the plasma glucose worth in an optimum class throughout the day. It assists transport blood glucose into the body cells where the glucose is metabolized to generate energy. Regular insulin is inserted premeal to abrupt the postprandial ascend in glucose levels. It figures hexamers after insertion into the subcutaneous space sluggishing its absorption. Ultra-fast acting commences to act 4-7 minutes before regular apidra and lasts for around 3 hours. The absorption rate of lente insulin is downgraded by the extension of zinc to the insulin preparation. Long-acting insulins furnish basal insulin coverage. Atrophy of subcutaneous fat owing to applicability of further greater accumulated insulin preparations of neutral potenz hydrogen.
\end{abstract}

Keywords: insulin; role

\section{Introduction}

\section{The discovery of insulin and function}

Insulin is a significant polypeptide hormone that regulates carbohydrate metabolism. Insulin is derived from the Latin word insula denotation "island" because the hormone is generated in the islets of langerhans. It was ascertained by Banting and Best in 1921-1922 at the University of Toronto [1]. Insulin is a peptide hormone that is produced and generated by beta cells in the Langerhans islets of the pancreas. A metabolic infirmity called diabetes happens as a sequence of insufficient insulin activity in the body or the degeneration in insulin production in beta cells. Thereupon, the find out of insulin has been a revolutionary climax in knowing both the treatment and auguring of diabetes [2,3]. The pancreas in a non-diabetic patient invariably produces a lesser quantum of insulin (basal production) [4]. After meals, a greater quantum of insulin is produced (bolus generation) to tolerate the escalated blood glucose that happens succeeding a meal [5]. The metabolism of glucose is actuated by food input, leading to coincidentally accelerated $\beta$ - cell insulin secretion and de-escalated $\beta$-cell glucagon production to yield serum glucose levels back to normal [6]. Succeeding production, insulin systemically circulates and is distributed to hepatocytes, which are quicker to deposit glucose in the figure of glycogen. Skeletal muscle cells and adipocytes, the distinctive considerable targets of circulating insulin, also take up glucose, thereby decreasing the blood glucose accumulation to commencement [7]. As with distinctive protein hormones, insulin actuates glucose uptake, and skeletal muscle protein production, glycogenesis, and lipogenesis through the tyrosine kinase receptor pathway $[8,9]$.

\section{The structure of insulin:}

Insulin has 51 amino acids and $6000 \mathrm{Da}$ molecular weight in nearly entire species, involving human. The human insulin molecule contains of dual polypeptide chains, lone " $\mathrm{A}$ " chain and lone "B" chain consisting 21 and 30 amino acid debris, respectively. These two chains are interlinked by SS (CysA7-CysB7 and CysA20-CysA19) with a disulfide bond, and an additional disulfide bond links CysA6 and CysA11 in chain A. The amino acids of the dual chains also partake in multiplex non-covalent interactions $[10,11]$. 


\section{Structure of human proinsuin and some commercialiy available insulin analogs. Insulin is shown as the shaded darker color) peptide chains, A and B. Differences in the $A$ and $B$ chains and amino acid modifications for insulin aspart, lispro, and glulisine are noted}

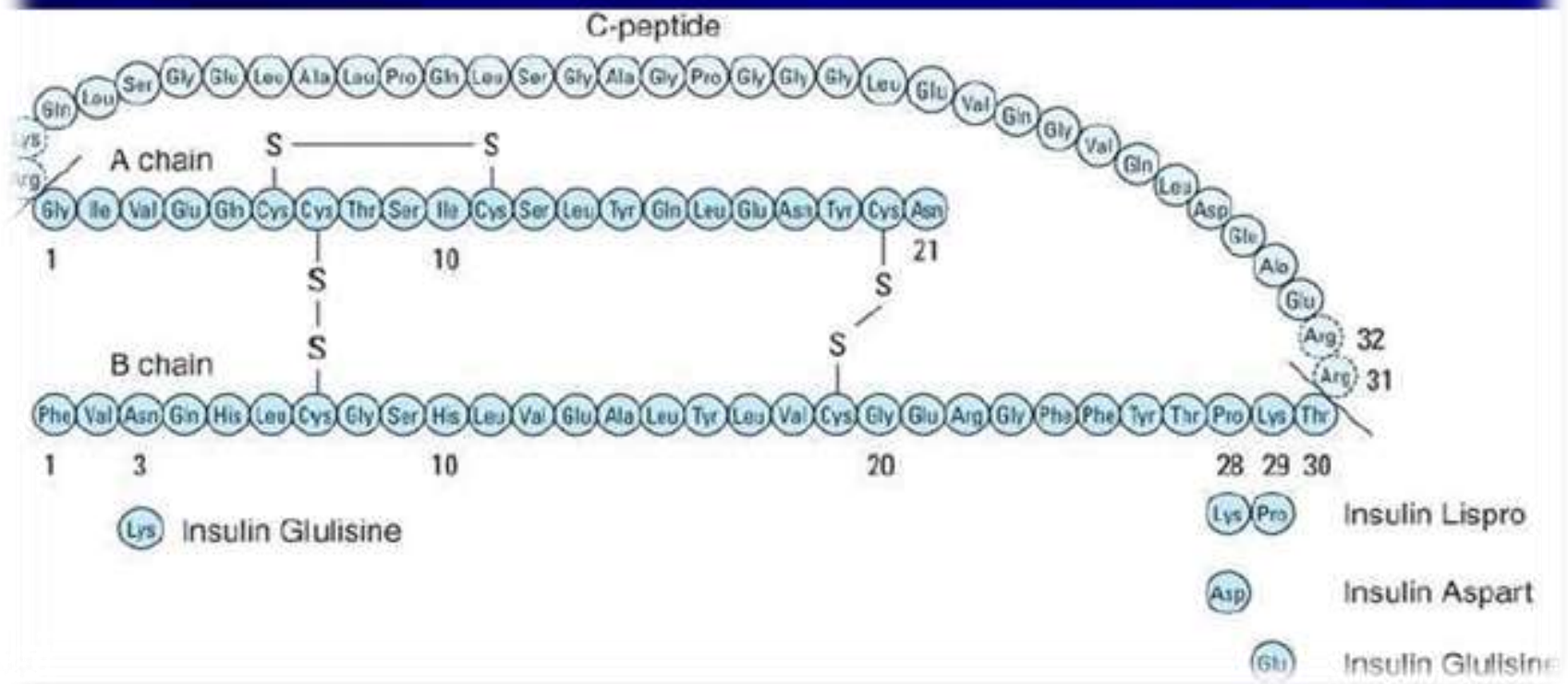

Figure-1. Schematic exemplify of human proinsulin structure

Factors enliven insulin production: Glucose, amino acids (leucine, arginine), hormones such as GLP-1, GIP, glucagon, great accumulations of fatty acids, and $\beta$-adrenergic sympathetic activity, Stimulatory medications are sulfonylureas, meglitinide and nateglinide, isoproterenol, and acetylcholine [12].

Factors suppress insulin production: Epinephrine is the great significant inhibitor, in emergency circumstances like stress, exercise and trauma, the nervous system enlivens adrenal medulla to secrete epinephrine and inhibit insulin generation [13].

The function of insulin: Insulin furnishes glucose homeostasis by considering the plasma glucose worth in an optimum class throughout the day [14]. It assists transport blood glucose into the body cells where the glucose is metabolized to generate energy. It vindicates glucose accumulation in the blood. When glucose accumulation in the blood is escalated, insulin smaller it by accelerating glucose uptake by muscle, liver and fat cells [15]. Surplus glucose is transformed to glycogen by these tissues. When glucose accumulation is downgraded in the blood, glycogen is transformed back to glucose and released in the blood. It is enclosed in regulating amino acid uptake by escalating DNA duplication and protein production [16]. Insulin facilitates fatty acid generation via the uptake of lipid from blood by fat cells. It also de-escalates proteinolysis, lipolysis and gluconeogenesis [17, 18]. It adjusts carbohydrate, fat, and protein metabolism by furnishing glucose in the blood to pass to fat, liver and skeletal muscle cells [19].

Sources of insulin: Human insulin is manufactured by bacterial recombinant DNA technology [20]. Remodeling of the amino acid resultant of human insulin has secreted insulins with otherness pharmacokinetic properties. The commencement of deed, peak consequence and lifetime of deed ascertained by insulin type and by physical and chemical figure of the insulin [21]. Insulin preparation is different in their times of commencement of activity and in their lifetimes of activity. This is owing to otherness in the amino acid resultants of the polypeptides, instance's dose, site of insertion, blood supplement, temperature, and physical activity can influence the lifetime of deed of the different preparations [22]. The applicable figures categorize from rapid-acting to long-acting [23]. The different insulin types applicable are:

(1) Rapid acting/rapid-onset and ultrashort-acting insulin preparations:

(1a) Regular insulin: Regular insulin is injected pre-meal to abrupt the postprandial ascend in glucose levels. It figures hexamers after injection into the subcutaneous area sluggishing its absorption [24, 25]. It is shortacting, soluble, crystalline zinc insulin. It is ordinarily bestowed subcutaneously (or intravenously in emergencies). It rapidly lesser blood sugar and are securely used in pregnancy [26].

(1b)Ultrashort-acting insulin: Grouped as ultrashort-acting insulins (because of their fast commencement and short lifetime of deed) [27]. These factors proffer further adjustable treatment regimens and minimize the pitfall of hypoglycemia and used in pregnancy solely if clearly necessitated. Commences to function in 15 minutes, peak near 1 hour and proceeds to function for around 2-4 hours [28].

Insulin lispro, insulin aspart and insulin glulisine: Insulin lispro is (Humalog) sequences from the reversal of the B28 (proline) and B29 
(lysine) amino acid resultant of insulin [29]. Insulin lispro has been attested for injection before and incontinently after a meal. Post-meal insulin dosing is applicable for parents of young children with type 1 diabetes, in whom the quantum of carbohydrates consumed at a meal can be unpredictable [30, 31]]. Insulin aspart is distinctive from human insulin by a substitution of the B28 amino acid proline with aspartic acid. Chemically it is B28-aspartic acid-human insulin. Fast-acting aspart adds two excipients, niacinamide and L-arginine, to conventional aspart [32]: Insulin glulisine disparate from human insulin by revamps' in the amino acid asparagine at place B3 to lysine and the lysine at place B29 to glutamic acid. Chemically, it is 3B-lysine-29B-glutamic acid-human insulin.

(2) Ultra-fast acting: Apidra (Fiasp) Which commences to act 4-7 minutes before regular apidra and lasts for near 3 hours [33].

(3) Short acting: Achieves systemic circulation in $30 \mathrm{~min}$, peaks after around 2-3 hours and stays active for about 3-6 hours. Instances of these preparations involve Actrapid, Humulin, Hypurin and Neutral. This insulin analogous should be injected into the body 20-30 min before meal so as to obtain optimal insulin activity for carbohydrate metabolism [34].

\section{(4) Intermediately acting: Intermediate-acting insulin preparations:}

(4a) Lente insulin: Lente word comes from the Latin "lentus," denotation slow, or sluggish) insulin [35]. The absorption rate of lente insulin is deescalated by the extension of zinc to the insulin preparation. Its commencement of deed and peak consequence are smaller than those of regular insulin, but are sustained for a lengthy period. Not convenient for intravenous administration [36].

(4b) Isophane NPH insulin suspension: Neutral protamine Hagedorn insulin: The absorption rate of NPH insulin is downgraded by the extension of protamine to the insulin preparation. NPH insulin is intermediate-acting insulin, whose commencement of deed is comparatively 2 hours; peak consequence is 6-14 hours, and lifetime of deed of 10-16 hours (basing on the size of the dose). Because of its wide peak and lengthy lifetime of deed, NPH can guarantee as basal insulin solely when dosed at bedtime or basal and prandial insulin when dosed in the morning [37, 38]. It is a suspension of crystalline zinc insulin joined at neutral $\mathrm{pH}$ with a positively charged polypeptide, protamine. Its lifetime of deed is intermediate (owing to holding pattern absorption of the insulin because of its conjugation with protamine, figuring a least soluble complex) [39]. It should solely be bestowed subcutaneously. It is serviceable in treating entire figures of diabetes exclude diabetic ketoacidosis or emergency hyperglycemia. Commencement of deed after 2-4 hours peaks 4-12 hours later and stays active for near 12-18 hours [40].

(5) Long acting: long-acting insulin preparations: Long-acting insulins furnish basal insulin content. Basal insulins inhibit hepatic gluconeogenesis to obviate glucose levels from ascending during the fasting state in insulin-defective patients. Aid patients with type 1 diabetes, basal insulins furthermore obviate ketogenesis [41]. Long-acting insulin can assist a person with diabetes regulate blood glucose outside of mealtimes [42].

(5a)Insulin glargine: The biological activity of insulin glargine is owing to its absorption kinetics and not an otherness pharmacodynamic activity (e.g., enliven of peripheral glucose uptake) [43]. Its further concordant rate of absorption and dearth of an important peak deed sequence in deescalated nocturnal hypoglycemia when insulin glargine is used at bedtime analogized with NPH insulin [44, 45]. The isoelectric point of insulin glargine is smaller than that of human insulin, leading to precipitousness at the injection site (prolonging its deed). It is smaller in commencement than NPH insulin and has extended hypoglycemic consequence. It has no peak (peakless) [46]. (5b)Insulin detemir: Insulin detemir is sluggishly absorbed owing to its durable consociation with albumin in the SQ tissue. Patients who proficiency an ascend in glucose levels in the hours preceding to a once quotidian injection owing to the waning deed of detemir should use a twice daily dosing regimen. It has consummate currently advanced long-acting insulin analogous [47, 48]. It is consociated with than NPH insulin. Has a dose-dependent hypoglycemic consequence and commencement of deed of 1-2 hours. Insulin detemir lifetime of deed is greater than 24 hours. It is bestowed twice daily and gradually absorbed from injection site owing to idiomatic preparation. Its activity can class from 18-24 hours. The ultra-long acting insulin degludec has plasma accumulations measurable besides 24 hours permitting for adjustable dosing $[49,50]$.

Insulin combinations: Different premixed combinations of human insulins [51]: Such as $70 \%$ NPH insulin $+30 \%$ regular insulin; $50 \%$ NPL insulin $+50 \%$ lispro insulin; $75 \%$ NPL insulin $+25 \%$ lispro insulin.

Insulin administration: It is administered by SQ injection, insulin is a polypeptide (it is breakdown in the gastrointestinal tract if taken orally). Regular insulin is bestowed I.V. injection in hyperglycemic emergency and I.V. infusion (to void multiplex injections) [52-54].

Basal-plus insulin: The extension of a single prandial insulin injection to the already existing basal regimen before the chief meal or the meal concordant with greatest PPG is referred to as a "basal-plus" technique $[55,56]$.

Basal-bolus regimen: Basal-bolus regimen is an amplified insulin therapy when target glycaemic control is not reached with basal insulin. This regimen imitates the physiological insulin production from the pancreas. The intermediate or long acting insulin is bestowed as basal insulin. The rapid or short acting insulin is bestowed as bolus insulin before meal. This regimen seeks often and active self-monitoring, knowledge on insulin-carbohydrate ratio and $\mathrm{CF}$, and titration of insulin dose to reach target glycaemic control $[57,58]$.

When you inject insulin, you should [59-61]: Use a fresh needle every time; conform you are bestowing the right type and dose of insulin; premier the needle every time to put off air and launch the circulate of insulin (also known as an "air shot"); insinuate the needle at 90 degrees (a right angle), if not considered differently by your health professional; after inserting the insulin, hang on to the needle beneath the skin for 10 seconds to make sure you obtain the full dose; revolve insertion sites so that you use a distinctive site any time to escape advancing fatty clots; if using an insulin pen, put off the needle from the pen after each injection; dispose of entire sharps.

Do not: Use the insulin after the expiry date; use the insulin if it doesn't appear the pace it should, or if it has been frozen or liable to excessive heat; shake the insulin too hard; insert in demesnes where there are scars, embellish labels or clots; inject through your clothes.

Storing insulin [62-64]: It's significant to store insulin appropriately: Store your unopened insulin in the fridge (away from the freezer/chiller section). Don't let your insulin freeze; preserve the insulin you are using at room temperature (below 25 degrees Celsius). Once insulin has been opened, it can remain at this temperature for up to 28 days; it's fine to preserve your recent insulin pen in your handbag or bag; don't preserve it in a place where it might get hot, like in your car or near a window; once open, dispose after 28 days.

Adverse reactions to insulin: (1) Hypoglycemia (further ubiquitous) owing to over dose (tachycardia, confusion, vertigo, diaphoresis) [65]: This type of hypoglycemia necessitated prompt counteract. Treatment of hypoglycemia: If the victim is conscious bestow him/her orange juice, glucose, Sugar containing beverage, food and also if the victim is unconscious (solemn hypoglycemia) use intravenous infusion of 20-50 $\mathrm{mL}$ of $50 \%$ glucose solution over a 2-3 minute. In the absence of 
intravenous infusion, $1 \mathrm{mg}$ of glucagon (SQ or IM administration), renew consciousness within around 15 minutes then food consumption lipodystrophy. (2) Atrophy of SQ fat owing to applicability of further greatly accumulated insulin preparations of neutral $\mathrm{pH}$. If insulin is inserted redundantly at the similar site of injection hypertrophy of SQ fatty tissue is happen [66]. (3) Allergic, and local injection site reaction occur with instantaneous type hypersensitivity, seldom urticaria pursues histamine release from tissue mast cells (sensitized by anti-insulin IgE antibodies) [67]. This allergic reaction treated by antihistamines, especially corticosteroids. (4) Weight gain [68]. (5) Insulin immune resistance owing to great titer circulating IgG anti-insulin antibodies [69].

Note: Diabetics with renal insufficiency perhaps need adjustment of the insulin dose [70]

\section{Conclusion}

Insulin is a peptide hormone that is generated and produced by beta cells in the Langerhans islets of the pancreas. A metabolic infirmity called diabetes happens as a sequence of insufficient insulin activity in the body or the degeneration in insulin production in beta cells. The foremost outcomes of insulin are: (i) In the liver, to enliven glucose oxidation and storage of glucose (glycogenesis), as well as to transform glucose into triglycerides and protein secretion, (ii) in the muscle tissue, it furnishes glucose uptake into the cells, and be stored as glycogen, (iii) and in fat tissue, it furnishes glucose uptake and transformation to triglycerides for storage. Regular insulin is injected pre-meal to abrupt the postprandial ascend in glucose levels. Short acting are achieves systemic circulation in 30 min, peaks after around 2-3 hours and stays active for about 3-6 hours

\section{Abbreviations}

ADRs: Adverse drug reactions; CF: Correction factors; CYP450: cytochrome P450; DI: Drug interaction; GIP: Glucose-dependent insulinotropic Polypeptide; GLP-1: Glucagon-like Polypeptide-1; PH: Potenz Hydrogen; P-gp: Pglycoprotein

\section{Acknowledgments}

The authors acknowledged Endnote-8, Google scholar, Medscape, Wikipedia, and PubMed.

Data Sources: Sources searched include Google Scholar, Research Gate, PubMed, NCBI, NDSS, PMID, PMCID, and Cochrane database. Search terms included: insulin function, type, side effects etc

\section{Funding}

None

\section{References}

1. Lewis, G.F.; Brubaker, P.L. The discovery of insulin revisited: Lessons for the modern era. J. Clin. Investig. 2021, 131, e142239.

2. Vecchio I, Tornali C, Bragazzi NL, Martini M. The Discovery of Insulin: An Important Milestone in the History of Medicine. Front Endocrinol (Lausanne) 2018; 9:613.

3. American Diabetes Association. Diagnosis and classification of diabetes mellitus. Diabetes care 2009; 33(Suppl 1):62-69.

4. Bolli GB, Porcellati F, Lucidi P, Fanelli CG. The physiological basis of insulin therapy in people with diabetes mellitus. Diabetes Research and Clinical Practice. 2021 May 1; 175:108839.

5. Lamont BJ, Waters MF, Andrikopoulos S. A low-carbohydrate high-fat diet increases weight gain and does not improve glucose tolerance, insulin secretion or $\beta$-cell mass in NZO mice. Nutrition \& diabetes. 2016 Feb; 6(2):e194-.
6. Vasiljevic, J.; Torkko, J.M.; Knoch, K.P.; Solimena, M. The making of insulin in health and disease. Diabetologia 2020, 63, 1981-1989.

7. Suckale, J.; Solimena, M. The insulin secretory granule as a signaling hub. Trends Endocrinol. Metab. 2010, 21, 599-609.

8. Yang, B.Y.; Zhai, G.; Gong, Y.L.; Su, J.Z.; Peng, X.Y.; Shang, G.H.; Han, D.; Jin, J.Y.; Liu, H.K.; Du, Z.Y.; et al. Different physiological roles of insulin receptors in mediating nutrient metabolism in zebrafish. Am. J. Physiol. Endocrinol. Metab. 2018, 315, E38-E51.

9. Lankisch MR, Ferlinz KC, Leahy JL, Scherbaum WA, Orals plus Apidra and LANTUS (OPAL) Study Group (2008) Introducing a simplified approach to insulin therapy in type 2 diabetes: A comparison of two single-dose regimens of insulin glulisine plus insulin glargine and oral anti-diabetic drugs. Diabetes Obes Metab 10: 1178-1185.

10. Steiner DF, Chan SJ, Welsh JM, Kwok SC. Structure and evolution of the insulin gene. Annu Rev Genet 1985; 19:463484.

11. Derewenda U, Derewenda Z, Dodson GG, Hubbard RE, Korber F. Molecular structure of insulin: the insulin monomer and its assembly. Br Med Bull 1989; 45:4-18.

12. Kennedy MS, Masharani U. Pancreatic hormones \& antidiabetic drugs. Basic and Clinical Pharmacology. New York: McGraw-Hill. 2018:747-741.

13. Gleeson M, Bishop NC, Stensel DJ, Lindley MR, Mastana SS, Nimmo MA. The anti-inflammatory effects of exercise: mechanisms and implications for the prevention and treatment of disease. Nature reviews immunology. 2011 Sep; 11(9):607615.

14. Qinna NA, Badwan AA. Impact of streptozotocin on altering normal glucose homeostasis during insulin testing in diabetic rats compared to normoglycemic rats. Drug design, development and therapy. 2015; 9:2515.

15. Güemes M, Rahman SA, Hussain K. What is a normal blood glucose?. Archives of disease in childhood. 2016 Jun 1; 101(6):569-574.

16. Zhu J, Thompson CB. Metabolic regulation of cell growth and proliferation. Nature reviews Molecular cell biology. $2019 \mathrm{Jul}$; 20(7):436-450.

17. Vecchio, I.; Tornali, C.; Bragazzi, N.L.; Martini, M. The Discovery of Insulin: An Important Milestone in the History of Medicine. Front. Endocrinol. 2018, 9, 613.

18. Csajbok, E.A.; Tamas, G. Cerebral cortex: A target and source of insulin? Diabetologia 2016, 59, 1609-1615.

19. AL O, EX F, RIMENTAL P, BASIC ME, IEN S. Insulin Structure, Function and Diabetes Models in Animals. Journal of Experimental and Basic Medical Sciences. 2020; 1(3):96101.

20. Stryjewska A, Kiepura K, Librowski T, Lochyński S. Biotechnology and genetic engineering in the new drug development. Part I. DNA technology and recombinant proteins. Pharmacological reports. 2013 Sep; 65(5):1075-1085.

21. Hirsch IB, Juneja R, Beals JM, Antalis CJ, Wright Jr EE. The evolution of insulin and how it informs therapy and treatment choices. Endocrine reviews. 2020 Oct; 41(5):733-755.

22. Akbarian M, Ghasemi Y, Uversky VN, Yousefi R. Chemical modifications of insulin: Finding a compromise between stability and pharmaceutical performance. International journal of pharmaceutics. 2018 Aug 25; 547(1-2):450-468.

23. Kochar IS, Sethi A. Real-world efficacy and safety of insulin degludec with mealtime rapid-acting insulin in type 1 diabetes in Indian pediatric population. International journal of pediatric endocrinology. 2018 Dec; 2018(1):1-7. 
24. Cobry E, McFann K, Messer L, Gage V, VanderWel B, Horton $\mathrm{L}$, et al. Timing of meal insulin boluses to achieve optimal postprandial glycemic control in patients with type 1 diabetes. Diabetes Technol Ther. 2010; 12:173-177.

25. Luijf YM, van Bon AC, Hoekstra JB, Devries JH. Premeal injection of rapid-acting insulin reduces postprandial glycemic excursions in type 1 diabetes. Diabetes Care. 2010; 33:21522155.

26. Kramer CK, Retnakaran R, Zinman B. Insulin and insulin analogs as antidiabetic therapy: A perspective from clinical trials. Cell Metabolism. 2021 Apr 6; 33(4):740-747.

27. Sharma DC. Emerging Injectable Therapies in Type 2 Diabetes Mellitus. RSSDI Diabetes Update 2018. 2019 Feb 28:22.

28. Gardner DW, Khan KA, Govindarajan G, Palmer JM, Sowers JR. Type 1 Diabetes Mellitus. InComprehensive Management of High Risk Cardiovascular Patients 2016 Apr 19 (pp. 173212). CRC Press.

29. Kristl A, Podgornik A, Pompe M. Simultaneous separation of insulin and six therapeutic analogues on a mixed mode column: HPLC-UV method development and application. Journal of Chromatography B. 2021 May 1; 1171:122557.

30. Tupola S, Komulainen J, Jaaskelainen J, Sipila I. Post-prandial insulin lispro vs. human regular insulin in prepubertal children with Type 1 diabetes mellitus. Diabet Med. 2001; 18:654-658.

31. Kumar D. Lispro analog for treatment of generalized allergy to human insulin. Diabetes Care. 1997; 20:1357-1359.

32. Heise T, Hovelmann U, Zijlstra E, Stender-Petersen K, Jacobsen JB, Haahr H. A Comparison of Pharmacokinetic and Pharmacodynamic Properties Between Faster-Acting Insulin Aspart and Insulin Aspart in Elderly Subjects with Type 1 Diabetes Mellitus. Drugs Aging. 2017; 34:29-38.

33. Ergun-Longmire B, Clemente E, Vining-Maravolo P, Roberts C, Buth K, Greydanus DE. Diabetes education in pediatrics: how to survive diabetes. Disease-a-Month. 2021 Feb 2:101153.

34. Jenkins AJ, Scott E, Fulcher J, Kilov G, Januszewski AS. Management of diabetes mellitus. InComprehensive Cardiovascular Medicine in the Primary Care Setting 2019 (pp. 113-177). Humana Press, Cham.

35. Akudike KP. Formulation and Evaluation of Physical Properties of an Emulsion Based on Lyophilized Snail Mucin for Possible Oral Insulin Delivery (Doctoral dissertation, University of Nigeria Nsukka).

36. Owens DR. Insulin preparations with prolonged effect. Diabetes technology \& therapeutics. 2011 Jun 1; 13(S1): S-5.

37. Almadhoun MR. Assessment of Medication Adherence and its Association with Glycemic Control among Type-2 Diabetes Mellitus (T2DM) Patients in Gaza-Palestine (Doctoral dissertation).

38. Chawla R, Chawla A. FAQs in Diabetes. JP Medical Ltd; 2016 Feb 12.

39. Beals JM, DeFelippis MR, Paavola CD, Allen DP, Garg A, Baldwin DB. Insulin. InPharmaceutical biotechnology 2019 (pp. 403-427). Springer, Cham.

40. Mikhael EM, Hassali MA, Hussain SA. A Self-management Guide for Type 2 Diabetes Mellitus Patients from Middle Eastern Countries. Cambridge Scholars Publishing; 2020 Jun 4.

41. Maikawa CL, d'Aquino AI, Lal RA, Buckingham BA, Appel EA. Engineering biopharmaceutical formulations to improve diabetes management. Science Translational Medicine. 2021 Jan $27 ;$ 13(578).

42. Semlitsch T, Engler J, Siebenhofer A, Jeitler K, Berghold A, Horvath K. (Ultra-) long-acting insulin analogues versus NPH insulin (human isophane insulin) for adults with type 2 diabetes mellitus. Cochrane Database of Systematic Reviews. 2020(11).
43. Yki-Jarvinen H, Dressler A, Ziemen M. Group HOEsS. Less nocturnal hypoglycemia and better post-dinner glucose control with bedtime insulin glargine compared with bedtime NPH insulin during insulin combination therapy in type 2 diabetes. HOE 901/3002 Study Group. Diabetes Care. 2000; 23:1130 1136.

44. Ratner RE, Hirsch IB, Neifing JL, Garg SK, Mecca TE, Wilson CA. Less hypoglycemia with insulin glargine in intensive insulin therapy for type 1 diabetes. U.S. Study Group of Insulin Glargine in Type 1 Diabetes. Diabetes Care. 2000; 23:639-643.

45. Heise T, Hermanski L, Nosek L, Feldman A, Rasmussen S, Haahr H. Insulin degludec: four times lower pharmacodynamic variability than insulin glargine under steady-state conditions in type 1 diabetes. Diabetes Obes Metab. 2012;14:859-864

46. Pettus J, Santos Cavaiola T, Tamborlane WV, Edelman S. The past, present, and future of basal insulins. Diabetes/metabolism research and reviews. 2016 Sep; 32(6):478-496.

47. Hubálek F, Refsgaard HH, Gram-Nielsen S, Madsen P, Nishimura E, Münzel M, Brand CL, Stidsen CE, Claussen CH, Wulff EM, Pridal L. Molecular engineering of safe and efficacious oral basal insulin. Nature communications. $2020 \mathrm{Jul}$ 27; 11(1):1-9.

48. Heise T, Mathieu C. Impact of the mode of protraction of basal insulin therapies on their pharmacokinetic and pharmacodynamic properties and resulting clinical outcomes. Diabetes, Obesity and Metabolism. 2017 Jan; 19(1):3-12.

49. Kennedy-Malone L. Endocrine, Metabolic, and Nutritional Disorders. Advanced Practice Nursing in the Care of Older Adults. 2018 Oct 31:361.

50. Ali MM, Aung KT, Young M, Eligar VS, Davies JS. Different insulin initiation regimens in patients with type 2 diabetes-a review article. Int J Diabetes Clin Res. 2018;5: 083.

51. Giugliano D, Ceriello A, Razzoli E, Esposito K. Defining the role of insulin lispro in the management of postprandial hyperglycaemia in patients with type 2 diabetes mellitus. Clinical drug investigation. 2008 Apr;28 (4):199-210.

52. Harak KV, Patil PB, Saudhagar RB. Current Challenges in Non-Invasive Insulin Drug Delivery System: A Review. Journal of Drug Delivery and Therapeutics. 2019 Jun 15;9 (3s):982-928.

53. Kennedy MS, Masharani U. Pancreatic hormones \& antidiabetic drugs. Basic and Clinical Pharmacology. New York: McGraw-Hill. 2018:747-741.

54. Banerjee A, Ibsen K, Brown T, Chen R, Agatemor C, Mitragotri $\mathrm{S}$. Ionic liquids for oral insulin delivery. Proceedings of the National Academy of Sciences. 2018 Jul 10;115 (28):7296-301.

55. Meneghini L, Mersebach $\mathrm{H}$, Kumar S, Svendsen AL, Hermansen K, et al. (2011) Comparison of 2 intensification regimens with rapid-acting insulin aspart in type 2 diabetes mellitus inadequately controlled by once-daily insulin detemir and oral antidiabetes drugs: The step-wise randomized study. Endocr Pract 17: 727-736.

56. Barnett A, Begg A, Dyson P, Feher M, Hamilton S, et al. (2008) Insulin for type 2 diabetes: Choosing a second-line insulin regimen. Int J Clin Pract 62: 1647-1653.

57. Frits H (2014) Insulin Regimens. DIAPEDIA.

58. Cobry E, McFann K, Messer L, Gage V, VanderWel B, Horton $\mathrm{L}$, et al. Timing of meal insulin boluses to achieve optimal postprandial glycemic control in patients with type 1 diabetes. Diabetes Technol Ther. 2010; 12:173-177.

59. Lynn P. Lippincott Photo Atlas of Medication Administration. Lippincott Williams \& Wilkins; 2018 Oct 5. 
60. Crasto W, Jarvis J, Davies MJ. Practical Aspects of Insulin Therapy. InHandbook of Insulin Therapies 2016 (pp. 169-209). Adis, Cham.

61. Thompson A, Lathan P, Fleeman L. Update on insulin treatment for dogs and cats: insulin dosing pens and more. Veterinary Medicine: Research and Reports. 2015; 6:129.

62. Keijer J, Li M, Speakman JR. What is the best housing temperature to translate mouse experiments to humans? Molecular metabolism. 2019 Jul 1; 25:168-176.

63. Wanders D, Burk DH, Cortez CC, Van NT, Stone KP, Baker M, Mendoza T, Mynatt RL, Gettys TW. UCP1 is an essential mediator of the effects of methionine restriction on energy balance but not insulin sensitivity. The FASEB Journal. 2015 Jun; 29(6):2603-2615.

64. Ngwiri T, Were F, Predieri B, Ngugi P, Iughetti L. Glycemic control in Kenyan children and adolescents with type 1 diabetes mellitus. International journal of endocrinology. 2015 Oct 1; 2015.

65. Paluchamy T. Hypoglycemia: Essential Clinical Guidelines. InBlood Glucose Levels 2019 Sep 30. IntechOpen.

66. Longenecker JZ, Petrosino JM, Martens CR, Hinger SA, Royer CJ, Dorn LE, Branch DA, Serrano J, Stanford KI, Kyriazis GA,
Baskin KK. Cardiac-derived TGF- $\beta 1$ confers resistance to dietinduced obesity through regulation of adipocyte size and function. Molecular Metabolism. 2021 Sep 25:101343.

67. Akinci B, Yener S, Bayraktar F, Yesil S. Allergic reactions to human insulin: a review of current knowledge and treatment options. Endocrine. 2010 Feb; 37(1):33-39.

68. Brown A, Guess N, Dornhorst A, Taheri S, Frost G. Insulinassociated weight gain in obese type 2 diabetes mellitus patients: What can be done? Diabetes, Obesity and Metabolism. 2017 Dec; 19(12):1655-1668.

69. Greenfield JR, Tuthill A, Soos MA, Semple RK, Halsall DJ, Chaudhry A, O'Rahilly S. Severe insulin resistance due to antiinsulin antibodies: response to plasma exchange and immunosuppressive therapy. Diabetic Medicine. 2009 Jan; 26(1):79-82

70. Teegen EM, Dürr M, Maurer MM, Eurich F, Vollbort A, Globke B, Bahra M, Blaeker H, Pratschke J, Eurich D. Evaluation of histological dynamics, kidney function and diabetes in liver transplant patients after antiviral treatment with direct-acting antivirals: Therapy of HCV-recurrence. Transplant Infectious Disease. 2019 Feb; 21(1):e13020.
This work is licensed under Creative Commons Attribution 4.0 License

To Submit Your Article Click Here:

Submit Manuscript
Ready to submit your research? Choose Auctores and benefit from:

$>$ fast, convenient online submission

$>$ rigorous peer review by experienced research in your field

$>$ rapid publication on acceptance

$>$ authors retain copyrights

$>\quad$ unique DOI for all articles

$>$ immediate, unrestricted online access

At Auctores, research is always in progress.

Learn more https://auctoresonline.org/journals/diabetes-and-islet-biology- 